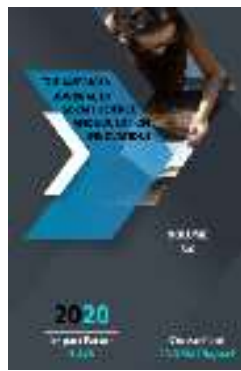

\title{
On The Stages Of The Ancient History Of The Tashkent Oasis
}

\author{
Rahmon Ziyodullaevich Ibragimov \\ National Center Of Archaeology Of The Academy Of Sciences Of The Republic Of Uzbekistan
}

Journal Website:

http://usajournalshub.c

om/index,php/tajssei

Copyright: Original

content from this work

may be used under the

terms of the creative

commons attributes

4.0 licence.

\section{ABSTRACT}

This article covers the issues of cultural development of the Tashkent oasis from the Bronze Age to antiquity. It contains a brief history of the archeological excavations carried out on the monuments of these periods, a description of the ideas put forward by the research scientist on the basis of their results and findings. The researchers' conclusions on the periodic date and economic issues of the history of the oasis were critically approached, new ideas were supplemented on the basis of comparative analysis, and enriched with the author's conclusions.

\section{KEYWORDS}

Tashkent oasis, Bronze Age, Early Iron Age, Antiquity, Burgulik culture, Kaunchi culture, settlement, tomb-fortress, Qang state, wool property.

\section{INTRODUCTION}

The Tashkent oasis is an important historical and cultural region located in the north-east of the Republic of Uzbekistan, in the middle reaches of the Syrdarya, one of the largest rivers in Central Asia. The province is bounded on the north and east by the Chatkal and Qurama Mountains, which belong to the Tianshan Mountain Range. The Chirchik and Ahangaron rivers flow from east to west along the oasis and flow into the Syrdarya. These lands differed from other Central Asian countries in ancient times with their favorable climate and nature. The foothills formed vast pastures. The river area was rich in trees. It is no coincidence that the medieval author Ibn Ruzbehkhan did not describe the Syrdarya region as a region rich in trees, various animals and birds that stretched to the sky $[1,154]$. 


\section{THE MAIN RESULTS AND FINDINGS}

The Chatkal-Qurama Mountains are rich in gold, silver, copper, iron, kaolin soils, precious stones, especially turquoise and other underground minerals. Medieval Arab tourists wrote that Khurosan and Turkestan were the leading regions in terms of the richness of the Chach and Ilaq underground mines $[2,21,26]$.

Favorable natural and geographical conditions of the Tashkent oasis attracted the ancestors of mankind. Material artifacts found here at Kolbulak, Obirahmat, Khodjakent, Qoshilish and other places belonging to different stages of the Stone Age, in particular, bone remains, testify to the fact that people have lived in the country since ancient times and life has continued uninterrupted.

In the III-II millennium BC, the Atlantic climate period ended and the peoples living in the northern part of the region and living on nomadic pastoralism were forced to migrate to the south due to the drying up of the weather in Eurasia. This process was migrating in the second millennium, in the last quarter they penetrated to the southern lands of Central Asia [3,6-62].

The study of the Bronze Age monuments of the Tashkent oasis, located between the nomadic pastoralists in the north and the settled peasantry in the south, began in the late 19th century. It was first studied in 1898 as the "Treasure of Chimbaylik" [4,69]. So far, about twenty monuments are known, consisting of random finds, a small number of tombs and settlements. Their description is described in the scientific works of A.I.Terenojkin, G.V.Oboldueva, M.E.Voronets, S.Rakhimov, H.Duke, F.A.Maksudov and S.R Ilyasova. None of the Bronze Age monuments found in the Tashkent oasis have undergone radocarbon analysis. Researchers have argued that the Andronov culture belongs to a particular stage on the external sign of material findings. E.E.Kuzmina summarized all the archaeological data and divided them into the last stage of the
Srub culture and the Fedorov stage of the Andronovo culture [3,61-62].

Researchers are limited in their scientific work to describing, comparing, and partially stating that material resources belong to a particular culture. Issues related to the socio-economic and religious relations of the Bronze Age of the country were left out of consideration.

The history of the Late Bronze and Early Iron Ages of the Tashkent oasis is reflected in the Burgulik culture. Basements, hand-made pottery and handicrafts of this culture were first studied by A.I.Terenojkin in 1940 during the construction of the Tashkent canal in the Burguliksay area. The researcher introduced a separate Burgulik culture based on the identified material findings [5,17-23]

In the early 705 of the $X X$ century Yu.F.Buryakov, G.Dadabaev in the area of the middle and lower reaches of the Chirchik River and identifies material objects 6.38-51].

Monuments of Burgulik culture were studied by $\mathrm{H}$. Duke in 1974-1977 in the middle reaches of the Ahangaron River, in the Tuyaboguz reservoir area. As a result of four years of research, the location of more than 50 houses from 11 settlements on both banks of the river was studied [7,57-73].

The houses of the Burgulik culture have much in common with the houses of the Tozabogyob culture, which are spread in the lands of the Akchadarya river in the lower reaches of the Amudarya. The size of the half-filled houses of the Tozabogyob culture is larger than that of the houses of the Burgulik culture. Wood was also used in the construction of houses belonging to the Tozabogyob culture. Such a construction is not found in Burgundy culture. Based on the similarity in housing construction, researchers link the origin of the Burgulik culture to the Togazabogyob culture [8,39-44].

The question of the chronology of Burgulik culture was analyzed by the scientific works of A.I.Terenojkin, H.Duke, Yu.F.Buryakov, 
M.I.Filanovich and divided into two stages (Burgulik I-mil. BC IX-VII centuries, Burgulik II millennium BC. VIIIV centuries) separated [9,153; 10,66;] S.R.Baratov compares the Burgulik culture with the new date of the monuments of the settled agricultural cultures of Central Asia, and its first stage was dated to the $13^{\text {th }}$ century $B C[11,13]$. As a result, the period of the Burgulik culture was dated to the XIII-IV centuries BC and lasts for ten centuries.

Archaeological excavations in the 1940s and 1970s revealed that the Burgulik culture farm consisted of agriculture, animal husbandry and handicrafts. Based on his observations in the territory of the Tuyaboguz reservoir, Yu.F. Buryakov said that the basis of the economy of the population of the Burgulik culture was irrigated agriculture. According to the researcher, the fields in the Tuyaboguz region were irrigated through a ditch taken from the Ahangaron River [12,160]. But both banks of the Ahangaron River are proluvial areas, where the inhabitants of ancient times did not have the opportunity to build irrigation facilities.

People living in the Tuyaboguz area were engaged in farming based on port-based irrigation of rain-fed crops at the foot of rivers. It is known from the experience of the Neolithic period that the productivity of portbased irrigation-based agriculture was considered to be very low. Port-based farming did not have the capacity to meet the food needs of the population [13, 86-87]. Most of the bones found in the Burgulik culture monuments belong to cattle. Therefore, in the Burgulik culture, animal husbandry prevailed, and agriculture formed a subsidiary farm. In general, the owners of Burgulik culture believe that Zoroastrianism was a type of tribe mentioned in the sacred book of the Avesta.

In the middle reaches of the Syrdarya from the second quarter of the first millennium, nomadic pastoral tribes dispersed. According to M.I. Filanovich, in the 6th century $B C$, the owners of the Burgulik culture assimilated into the nomadic population from the Eurasian steppes and took the form of animal husbandry $[14,15]$. Examples of their material culture date back to the Chordara region 1 tomb-fortress of Jomantuba cemetery of VII-VI centuries has been identified. The materials found in the Burchmullo tomb in the Tashkent oasis was dated in the $\mathrm{V}$-III centuries $B C$ $[15,103]$. These monuments confirm the opinion of M.I.Filanovich.

H. Duke built a trench 20-25 m wide, 2-2.5 m deep and $40-42 \times 24 \times 12 \mathrm{~cm}$ on three sides of the settlement on the left bank of the Ahangaron River (Location 1) noted a 2-meter-thick defensive wall made of dimensional raw brick. This address was dated to the IX-VIII centuries $B C$ and is described as an emerging city [7,5273]. During this period, in the southern agricultural centers of Central Asia (Bactria, Sogd, Margiyana) there was a complex of the first phase of the spring. They are considered to be on a par with the first stage of Burgulik culture, and there are close similarities in material culture and economics. In the next stage, the irrigation system in the southern regions was improved and old towns was appeared instead of agricultural villages. In the Burgulik culture, however, there are no changes in the field of economy and material culture, and the tradition of port-style farming and construction of basement houses is preserved. The unchanging continuity of economic and material culture for ten centuries has not been observed in any part of Central Asia.

Therefore, it is scientifically expedient to consider the second-Burgulik II stage of Burgulik culture (VIII / VII-IV centuries BC) as a separate cultural complex on the basis of the materials of few archeological monuments identified in the middle reaches of the Syrdarya and comparison with neighboring areas.

Information about the ancient cattle-breeding Sak tribes is preserved in the rock inscriptions of Herodotus ( $\mathrm{VI}$ century BC), Hellanica ( $\mathrm{V}$ century), Bekhustun rock of Darius I. These written sources include "Sogdian Orti Saks", 
"Yaksart Orti Saks", "Xaoma Preparatory Saks", "Tigrahauda Saks". Some of them lived beyond the Syrdarya, especially in the Tashkent oasis. Based on these data and the tombs of Jomantuba 1 and Birchmulla mentioned above, it would be a scientifically correct conclusion to accept the second stage of the Burgulik culture as an archeological complex belonging to the Saks.

From the last quarter of the 4th millennium BC, the influence of Sogdian culture began behind the Syrdarya. From the lower stratum of the ancient city near the city of Shymkent in southern Kazakhstan, just like the Sogdian Pottery such as pottery from the V-IV centuries was found [16,22-35]. When Alexander the Great's armies marched on Sogdia in the 329 $\mathrm{BC}$, those potteries were belonged to the retreating population of the Syrdarya.

In the Tashkent oasis, urbanization, which has played a leading role in the cultural development of society, was formed much later than in all other settled agricultural centers of Central Asia. Country cities were formed under the cultural influence of neighboring areas. The ancient cities of the Tashkent oasis first appeared on the right bank of the middle reaches of the Syrdarya, in the area from Bekabad to the north-west to the Chordara reservoir.

Ancient written sources state that the Seleucid general Demodam crossed the Yaksart (Syrdarya) and built a fortress (city) to resist the nomadic Scythians (sak). The first Shahristan (Shahristan I) defensive wall of Qanqa settlement, located $70 \mathrm{~km}$ south of Tashkent in the territory of Akkurgan district,

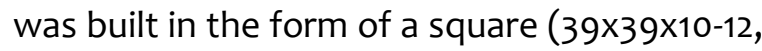
$40 \times 40 \times 10-12 \mathrm{~cm}$ ) raw brick in ellinic architecture and F.Buryakov relays that it was located in the city which was built by Demodam. $[10,106]$. Thus, in the Tashkent oasis is the first city was formed in the IV / III century BC. This city was Antioch of Yaksart.
The next stage of cultural development in the Tashkent oasis is associated with the formation of the Kaunchi culture. According to L.M. Levina, some tributaries of the Syrdarya It became dehydrated in the III-II centuries. As a result, the Babishmasty. Another group came to the Tashkent oasis and created the Kaunchi culture. The monuments of material culture of the Kaunchi, in particular, the buckle depicting the lying position of the camel, the pottery are similar to the samples of material culture of the Eastern Aral Sea region and the Prokhorov culture of the Sarmatians (IV / III-II centuries BC) [18,84-92]. The development of urban planning, irrigated agriculture and metallurgy is a characteristic feature of the Kaunchi culture. Shoshtepa residential complex is very close to the architecture of the Eastern Aral Sea and Khorezm.

Sedentary agricultural settlements belonging to the first stage of the Kaunchi culture, in particular, the ruins of the ancient city, are mainly distributed in the areas from the middle reaches of the Chirchik and Ahangaron rivers to the Syrdarya in the south. Livestock tribes lived in the hills and foothills of the Tashkent oasis. The tomb-monuments belonging to them have been preserved.

A written source from the Han period of China ( $A D$ 3rd -3rd centuries $B C$ ) lists the Qang state, which included five small estates (Suse, Fumu, Yuni, Gi, Yuegyan). Its capital was the city of Bityan, located on the lands of Loyueni $[19,150$; 186]. Researchers place the property of Yuni or Loyue in the Tashkent oasis.

One of the important issues is to study the relationship between the Qang state and the Kaunchi culture. Based on data from Chinese sources, the formation of the Qang state dates back to marking with the II century $B C$ has become a tradition. K.Sh. Shoniyazov ruled over the Qang state is believed that it originated in the middle of the century as a result of the struggle of the local nomadic population against the Seleucid dynasty in the early III century $[20,118]$. B.A. Litvinsky 
considers the Kaunchi Complex I as the first stage of the Qang state and the last Sak state $[21,27]$. Qang state appeared before the II century $B C$, during the formation of the Kaunchi culture, and their date is not later than the third century.

In the first stage of the Kaunchi culture, the power of the Qang state increased and the urban culture further developed. The capital of the country, Bityan (Qanqa), will expand and become a major trade and production center. During this period, its area expanded to 150 hectares and was surrounded by a new defensive wall. New urban centers are emerging in the oasis. Ancient cities such as Shokhrukhiya, Oktepa 2 (Southern Kazakhstan), located along the Kovunchitepa, Shoshtepa, Zangoritepa, Akkurgan and Syrdarya rivers, was appeared. Based on the results of his research, Yu.F. Buryakov states that the city, which replaced Shahrukhiya, was formed in the I century [22, 78-80]. The history of the ancient city has a square shape (sides $600 \times 600 \mathrm{~m}$.), The main part of which, especially the arch, was completely destroyed in the Syrdarya flood. According to researchers, the defensive wall of Oktepa 2 was built during this period [23,11-17].

\section{CONCLUSION}

In general, during this period, the growth of the Qang state, on the one hand, and the development of foreign trade along the Great Silk Road, played an important role in the cultural development of the Tashkent oasis, especially in the development of urbanization. A branch of the trade route from China through the Fergana Valley, along the Syrdarya, through the territory of the Tashkent oasis, passed through the pass near the Shahrukh settlement and headed for Sogd. Another network went along the river to the Aral Sea region of Yangtze. The Great Silk Road had a positive impact on the trade, economic and cultural development of the Tashkent oasis.
In later Chinese sources, the toponym Yuni is given by the names Shi, Chjeshi (Chjesi). The term "Shi" means stone in Chinese. Yu.F.Buryakov believes that it was used for the turquoise stone, which is a symbol of victory. Archaeological evidence has shown that turquoise was mined from deposits such as Feruzakon and Aktashkon in the Qurama Mountains.

The history of the last ancient period of the Tashkent oasis is mentioned in the written monuments of the Sassanid king Shopur I in the Zoroastrian tomb. It mentions the name Chach or Chachistan for the first time [24,68]. Some researchers believe that the term Chach is the oldest of the Saxon period, with its territorial boundary extending to the Aral Sea.

In general, the climate and rich nature of the Tashkent oasis have created favorable conditions for human habitation since ancient times. The favorable natural conditions of the oasis led to the long-term preservation of the ancient economic traditions of the population. During the Bronze Age, when the first urban culture was formed in the southern regions of Central Asia, nomadic tribes engaged in animal husbandry in the Tashkent oasis. Cities appeared much later in the country. Cities came into being under the direct cultural influence of neighboring areas (Qanqa, Qovunchitepa, Shoshtepa, etc.). The underground ore deposits of the ChatkalQurama Mountains played an important role in the socio-economic and cultural development of the country in ancient times. The fact that the international trade route passes through the oasis is also an important factor in economic and cultural development.

\section{REFERENCES}

1. Past Kazakhstan. - Alma-Ata, 1935. T. 1. S. 154.

2. Istaxri. Kitab masalik-al-mamalik // Materials on the history of Kyrgyzstan and Kyrgyzstan. Izd. e. Bishkek 2002. S. 21, 26. 
3. Kuzmina E.E. Arii-put on yug. M.-Spb., «Letniy sad» 2008. -S.61-62.

4. Voronets M.E. Bracelets of bronze epoxy Museum of History AN UzSSR, Trudy IIA AN UzSSR, T I, Tashkent, 1948, -S.69

5. Terenojkin A.I.Sogd and Chach. KSIIMK, vyp. XXXIII. M-L., 1950. -S 153 and 155, fig. 69, $\mathrm{XVI}, \mathrm{XVII}$.

6. Buryakov Yu.F., Dadabaev G. Pamyatniki antichnogo vremeni Tashkentskom oasis. IMKU №10, Tashkent “Fan”, 1973. -S. 38-51.

7. Duke X.Tuyabuguzskie poselenie burgulyukskoy kultury. Tashkent. "Fan" $1982-$ S. $57-73$

8. Bendezu-Sarmiento J., Lhuillier J. Between Nomadic and Sedentary Cultures: study the Ancient 8.Iron Age cultures of in Chach. Is it possible to speak about an influence of Khorezm? Role of Tashkent city in development world civilization.Materials of the International Scientific Conference devoted to the 2200 th Anniversary of the City of Tashkent. Tashkent, "Fan", 2009.

9. Terenojkin A.I.Sogd and Chach. KSIIMK, vyp. XXXIII. M-L., 1950. -S 153 and 155, fig. 69, $\mathrm{XVI}, \mathrm{XVII}$.

10. Buryakov Yu.F. Genesis and stages of the city and city culture of the Tashkent oasis Tashkent, "Fan", 1982.-S. 66;

11. Baratov S.R. Burgulik culture. // Archeology of the Tashkent oasis. Tashkent, UNESCO, 2008. -P.13.

12. Alimov K., Buryakov Yu.F., Duke X. Ancient Tuyabuguza. Tashkent. "Fan" 1978, -S.160.

13. Masson V.M. Djeytun's visit. L., "Nauka" 1971, $-\mathrm{S} .86-87$

14. Filanovich M.I. Old Shosh town. // Archeology of the Tashkent oasis. Tashkent, UNESCO, 2008. -P.15

15. Zadneprovskiy Yu.A. Early nomads of South Kazakhstan and the Tashkent oasis // Archeology of the USSR. Stepnaya strip Aziatskoy chasti SSSR in skifo-sarmatskoe vremya. - Moscow: Nauka, 1992. - p. 103, tabl. 37

16. Suleymanov R.X., Baytanaev B.A. Stratigrafiya gorodishcha Shymkent: vozniknovenie i razvitie goroda // Drevnyaya i srednevekovaya urbanizatsiya Evrazii i vozrast goroda Shymkent. Materials nauchno-prakticheskoy conference. October 16, 2008 Shymkent, 2008.-S.22-35.

17. Levina L.M. Ethnocultural history of Vostochnogo Priaralya. I tysyachiletie do n.e.-I tysyachiletie n.e. M., "Eastern literature", 1996, p.5-6.

18. Filanovich M.I.Drevnyaya i srednevekovaya istoriya Tashkenta $\mathrm{v}$ archeologicheskix istochnikax.Tashkent, 2010, S.-84-92

19. Bichurin N.Ya. (lakinf). Gathering of witnesses of the peoples living in Central Asia in ancient times. M, 1950. T. II. -S. 150, 186.

20. Shoniyozov K.Sh. The process of formation of the Uzbek people. T., "Sharq", 2001, 118 pages.

21. Litvinskiy B.A. Kangyuysko-sarmatskiy farn. Dushanbe, 1968.-S.27

22. Ancient and srednevekovby city of Vostochnogo Maverannaxra. T., "Fan" 1990. S.78-80

23. Maksimova A.G., Mershchiev M.S., Weinberg B.I., Levina L.M. Drevnosti Chordary (Archaeological research in the zone Chardarinskogo vodakhranilishcha). Alma-Ata, 1968, -S.11-17

24. Lukonin V.G.Kultura sasanidskogo Irana. M., 1969.-S.68.

25. Nazarov, A. Y. (2019). THE FUND OF NATIONAL ARCHIVE OF UZBEKISTAN ABOUT THE SCIENTIFIC INSTITUTIONS IN TURKESTAN. Theoretical \& Applied Science, (10), 587-589.

26. Nazarov, A.Y. (2016). Organization of the use of documents from the Central State Archive of Cinema, Photo, Phono Documents of the Republic of Uzbekistan. Document. Archive. History. Modernity. Yekaterinburg, 2016, 484-489.

27. Nazarov, A. (2020). History Of The Emergence And Development Of Scientific Societies In The Governor-General of Turkestan. The American Journal of Social Science and Education Innovations, 2(10), 82-88. 
The American Journal of Social Science and Education Innovations (ISSN - 2689-100x)

Published: November 23, 2020 | Pages: 86-92

Doi: https://doi.org/10.37547/tajssei/Volume02Issue11-15

2020: $5 \cdot 525$

28. Omonov, Q., \& Karimov, N. (2020). Importance Of Ancestoral Heritage. The American Journal of Social Science and Education Innovations, 2(09), 196-202. 